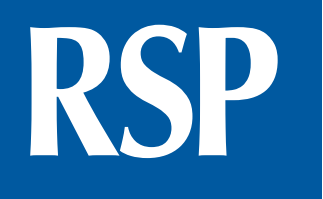

http://www.rsp.fsp.usp.br/

Revista de Saúde Pública

\title{
Association between the concentration of fine particles in the atmosphere and acute respiratory diseases in children
}

Antônio Paula Nascimento', Jane Meri Santos", José Geraldo Mill"', Juliana Bottoni de Souzalv, Neyval Costa Reis Júnior", Valdério Anselmo Reisenv

I Departamento de Tecnologia Industrial. Universidade Federal do Espírito Santo. Vitória, ES, Brasil

" Departamento de Engenharia Ambiental. Universidade Federal do Espírito Santo. Vitória, ES, Brasil

II' Departamento de Ciências Fisiológicas. Universidade Federal do Espírito Santo. Vitória, ES, Brasil

Iv Programa de Pós-Graduação em Saúde Coletiva. Universidade Federal do Espírito Santo. Vitória, ES, Brasil

$\checkmark$ Departamento de Estatística. Universidade Federal do Espírito Santo. Vitória, ES, Brasil

\section{ABSTRACT}

OBJECTIVE: To analyze the association between fine particulate matter concentration in the atmosphere and hospital care by acute respiratory diseases in children.

METHODS: Ecological study, carried out in the region of Grande Vitória, Espírito Santo, in the winter (June 21 to September 21, 2013) and summer (December 21, 2013 to March 19, 2014). We assessed data of daily count for outpatient care and hospitalization by respiratory diseases (ICD-10) in children from zero to 12 years in three hospitals in the Region of Grande Vitória. For collecting fine particulate matter, we used portable samplers of particles installed in six locations in the studied region. The Generalized Additive Model with Poisson distribution, fitted for the effects of predictor covariates, was used to evaluate the relationship between respiratory outcomes and concentration of fine particulate matter.

RESULTS: The increase of $4.2 \mu \mathrm{g} / \mathrm{m}^{3}$ (interquartile range) in the concentration of fine particulate matter increased in $3.8 \%$ and $5.6 \%$ the risk of medical care or hospitalization, respectively, on the same day and with six-day lag from the exposure.

CONCLUSIONS: We identified positive association between outpatient care and hospitalizations of children under 12 years due to acute respiratory diseases and the concentration of fine particulate matter in the atmosphere.

DESCRIPTORS: Child. Particulate Matter. Adverse Effects. Air Pollution. Respiratory Diseases. Epidemiology.

\footnotetext{
How to cite: Nascimento AP, Santos JM, Mill JG, Souza JB, Reis Júnior NC, Reisen VA. Association between the concentration of fine particles in the atmosphere with acute respiratory diseases in children. Rev Saude Publica. 2017;51:3.

Copyright: This is an open-access article distributed under the terms of the Creative Commons Attribution License, which permits unrestricted use, distribution, and reproduction in any medium, provided that the original author

and source are credited.

Antônio Paula Nascimento

de Camburi

Received: 1 Jul 2015

Approved: 14 Nov 2015
} 


\section{INTRODUCTION}

Air pollution is associated with problems to human health and loss of quality of life ${ }^{16}$. Air pollutants fall into two categories: gases $\left(\mathrm{O}_{3}, \mathrm{NO}_{2}, \mathrm{SO}_{2}, \mathrm{CO}\right.$, for example) and particulate matter (PM), with different grain sizes and chemical composition. These pollutants have been linked to adverse health effects even in low concentrations ${ }^{9,18}$, especially PM, the most responsible for health problems related to the respiratory system ${ }^{24}$. The harmful effect to human health caused by PM depends both on its concentration in the inhaled air and on its granulometry and chemical composition. Chemical composition, granulometry, and concentration of PM in the atmosphere depend, especially, on its sources, which can be natural or anthropogenic (processing, mining, construction industries; vehicular emissions; among others), and on the emission intensity.

The PM is classified according to its aerodynamic diameter (varies from few nanometers to $100 \mu \mathrm{m})^{3}$. In addition to sedimentary particles (SP) that cause discomfort, the inhalable PM harmful to health are divided into three groups: particles with diameter lower than or equal to $10 \mu \mathrm{m}\left(\mathrm{PM}_{10}\right)$, fine particles with diameter lower than or equal to $2.5 \mu \mathrm{m}\left(\mathrm{PM}_{2.5}\right)$, and ultrafine particles with diameter lower than or equal to $0.1 \mu \mathrm{m}^{10,24}$. The harmful effects of $\mathrm{PM}_{2.5}$ occur in the short term, by direct action on the airways, and in the long term, because, once inhaled, it can reach the alveoli, get to the bloodstream, and affect other organs besides the lungs ${ }^{5}$. Thus, $\mathrm{PM}_{2.5}$ presents potential health risk even when in relatively low concentrations in the atmosphere, i.e., even when its atmospheric concentration is below the maximum levels of tolerance established by the World Health Organization (WHO) and by the main environmental regulatory agencies of the world ${ }^{15,24}$.

Studies show the association between air pollution and incidence of respiratory, cardiovascular, neurological diseases and several types of cancer ${ }^{10,14,24}$. The association with respiratory diseases is stronger and direct, and the most vulnerable groups are children, older adults, and those with pre-existing respiratory diseases, especially asthma, chronic bronchitis, and chronic obstructive pulmonary disease ${ }^{3,5,19}$. Epidemiological studies quantify the impact of $\mathrm{PM}_{2.5}$ concentration and the incidence of acute morbid events in an attempt of seeking minimum levels of safety for exposure ${ }^{13,15}$. The triggering of asthma, bronchitis, and pneumonia attacks is often associated with the increase of air pollution by $\mathrm{PM}^{3,17}$ and gases.

However, the relationship between concentration of PM in the atmosphere and incidence of diseases presents inconsistencies, because concentration, by itself, may not be the only reason for harmful effects to health. The presence of some chemical element in PM, even in small concentrations, may also be associated with the occurrence of diseases ${ }^{9,14}$. There are few Brazilian studies relating PM $_{2.5}$ with problems to human health ${ }^{17}$.

This study aimed to evaluate the association between concentration of $\mathrm{PM}_{2.5}$ in the atmosphere and incidence of acute respiratory events in children from zero to 12 years old.

${ }^{a}$ Environmental Protection Agency (US). Model quality assurance project plan for the PM ambient air 2.5 monitoring program at State and Local Air Monitoring Stations (SLAMS). Durhan: Environmental Protection Agency; 1998 [cited 2014 Apr 8]. (Draft Report - EPA-454/R-98-005). Available from: https://www3. epa.gov/ttn/amtic/files/ambient/ pm25/qa/totdoc.pdf

\section{METHODS}

This is an ecological study, carried out in the Region of Grande Vitória (RGV), Espírito Santo, in the winter (June 21 to September 21, 2013) and summer (December 21, 2013 to March 19, 2014). Samples of $\mathrm{PM}_{2.5}$ in the atmosphere were collected in six stations located in the cities of Serra, Vitória, Vila Velha, and Cariacica (urban and industrialized region) in those periods (Figure 1). The samples were collected on alternate days during winter and summer, in continuous periods of 24 hours, with start of measurement on midnight. The concentration of $\mathrm{PM}_{2.5}$ in $\mathrm{RGV}$ was determined by the arithmetic mean of the values detected in the six stations.

We used Mini-Vol portable samplers (Airmetrics - USA), developed in conjunction with the United States Environmental Protection Agency (U.S.EPA) and already used in 
other studies ${ }^{1,23}$. The filters for sampling $\mathrm{PM}_{2.5}$, with $47 \mathrm{~mm}$ diameter and efficiency for retention of particles of up to $0.3 \mu \mathrm{m}$, met the standard $\mathrm{MB}-3422^{\mathrm{b}}$ and recommendations of the code 40 CFR Part 50 Appendix $L^{c}$. The filters were accommodated in desiccator for 24 hours $\left(20^{\circ} \mathrm{C}\right.$ to $23^{\circ} \mathrm{C}$ and humidity between $30.0 \%$ and $\left.40.0 \%\right)$ for initial weighing and gravimetric quantification after neutralization of static electrical charges ${ }^{\mathrm{a}}$. We used an analytical balance (Sartorius - Germany), with sensitivity of $1 \mu \mathrm{g}$, for the gravimetric analysis. The mean daily concentration of $\mathrm{PM}_{2.5}\left(\mu \mathrm{g} / \mathrm{m}^{3}\right)$ was calculated by the ratio between the mass of $\mathrm{PM}_{2.5}$ and the total volume of sampled air in Mini-Vol, considering the mean uncertainties of weighing of the white filters of laboratory and field ${ }^{\mathrm{a}, \mathrm{b}}$.

Weather variables (temperature, relative humidity) were obtained from the Weather Network located at Eurico de Aguiar Salles Airport ${ }^{\mathrm{d}}$.

The data of emergency care and hospitalization of children from zero to 12 years were obtained during the periods of measurement of $\mathrm{PM}_{2.5}$ in three hospitals: Hospital Infantil Nossa Senhora da Glória (HINSG), main pediatric emergency room in the region, Hospital Unimed Vitória, and Hospital Santa Rita de Cássia, the first being public and the other two, private. These hospitals do not represent the totality of care, but show a significant portion of the urgency/emergency care in RGV, mainly by the high volume of patient care at HINSG, specialized in pediatric patients. We considered as "acute respiratory events" those encoded from JJ00 to JJ99 in the International Classification of Diseases (ICD-10): diseases of the upper airways (rhinitis, sinusitis, and pharyngitis) and lower airways (asthma, pneumonia, bronchitis, bronchiolitis, and obstructive pulmonary diseases). We have included only the care to children with home accommodation in the four cities of RGV (Figure 1). The care of a patient already previously seen was considered as new event if the interval between the sessions was higher than seven days. For an event to be inserted in the database of this study, the medical record should present: name, home address of the child, sex, date of birth, and diagnosis.

The association between atmospheric concentration of $\mathrm{PM}_{2.5}$ and daily incidence of acute respiratory events was investigated by the Generalized Additive Model (GAM) with Poisson distribution. The use of GAM has been explored in other studies ${ }^{6,711}$. We included in the model, as explanatory covariates (besides the concentration of $\mathrm{PM}_{2.5}$ ), the collection period (winter/summer), seasonality of short duration (days of the week), holidays, seasonality of long duration (number of elapsed days), and weather variables (temperature and relative humidity) ${ }^{2,8}$. GAM enables the modeling of the non-linear relationship between explanatory and outcome variables, including parametric and non-parametric functions to enable the data curve fitting. The outcome variable (hospitalization/emergency care) corresponds to a discrete probability distribution because it is a process of counting non-negative integers, which follows Poisson distribution.

$\operatorname{Be}\left\{Y_{t}\right\}, t=1, \ldots, N$, a time series of count of non-negative integers. The conditional density function of $\left\{\mathrm{Y}_{\mathrm{t}}\right\}$ given passed information $\left(F_{\mathrm{t}-1}\right)$, denoted by $\left\{\mathrm{Y}_{\mathrm{t}} \mid F_{\mathrm{t}-1}\right\}$, has Poisson distribution, with mean $\mu_{\mathrm{t}}$, if it meets:

$$
\mathrm{f}\left(\mathrm{y}_{\mathrm{t}} ; \mu_{\mathrm{t}} \mid F_{\mathrm{t}-1}\right)=\frac{\mathrm{e}^{-\mu_{\mathrm{t}}} \mu_{\mathrm{t}}^{\mathrm{y}_{\mathrm{t}}}}{\mathrm{y}_{\mathrm{t}}^{!}}, \mathrm{t}=1,2, \ldots, \mathrm{N},
$$

where $y_{t}$ represents hospitalization/emergency care at moment (day) t.

Be $X=\left(X_{1}, X_{2}, \ldots, X_{p}\right)$ a vector of $p$ explanatory covariates. The curve that describes the relationship between $\mathrm{y}_{\mathrm{t}}$ and the covariates $\mathrm{X}$ is obtained by the logarithmic transformation of $\mu_{\mathrm{t}}$ given by equation (2).

$\log \left(\mu_{\mathrm{t}}\right)=\alpha+\sum_{\mathrm{j}=1}^{\mathrm{q}} \beta_{\mathrm{j}} \mathrm{X}_{\mathrm{j}}+\sum_{\mathrm{j}=\mathrm{q}+1}^{\mathrm{p}} \mathrm{f}\left(\mathrm{X}_{\mathrm{j}}\right)$, being

where $\alpha$ is the model intercept; $\beta_{\downarrow j}(j=1, \ldots, q)$ represent the linear regression coefficients associated with the concentration of $\mathrm{PM}_{2.5}$ and with indicative covariates for the days of 
the week, holidays, seasons (winter/summer); and $\mathrm{f}\left(\mathrm{X}_{\mathrm{J}}\right)$ are smoothing spline functions for confusion variables (temperature and humidity) and temporal trend variables (number of elapsed days) ${ }^{17,22}$. The spline function allows the control of the nonlinear dependence between the covariates and outcome variable ${ }^{8,17}$.

The GAM fitting was obtained after analyses considering the temporal trend, seasonality, data correlation with time by the auto correlation function (ACF). We applied usual tests of residuals and goodness of fit using the Akaike criterion (AIC).

The relative risk $(\mathrm{RR})$ is a measure of occurrence between the probability of an epidemiologic event ${ }^{4}$ occurring given the exposure to certain level of the exposure factor in relation to those affected by the same event and not exposed to the factor. In this study, RR refers to the increased risk of acute respiratory events occurring given the exposure of concentration levels of $\mathrm{PM}_{2.5}$.

For the GAM with usual Poisson distribution, RR is expressed by equation (3).

$$
R R(x=k)=e^{(k \cdot \beta i)} \text { with } \mathrm{i}=1,2, \ldots, p
$$

Being $\mathrm{k}$ the concentration variation of $\mathrm{PM}_{2.5}$, here considered by the difference between the third and first quartiles, and $\hat{\beta}$ the coefficient estimated by GAM.

Data were supplied as mean and standard deviation (SD) and outcome as counts. We used a significance level of $5 \%$. The process of modeling and statistical analysis were made on the R platform.

The project was approved by the Research Ethics Committee (CEP) of the Brazilian Ministry of Health (CAAE 080197 12.6.0000.5542) and other committees of the hospitals.

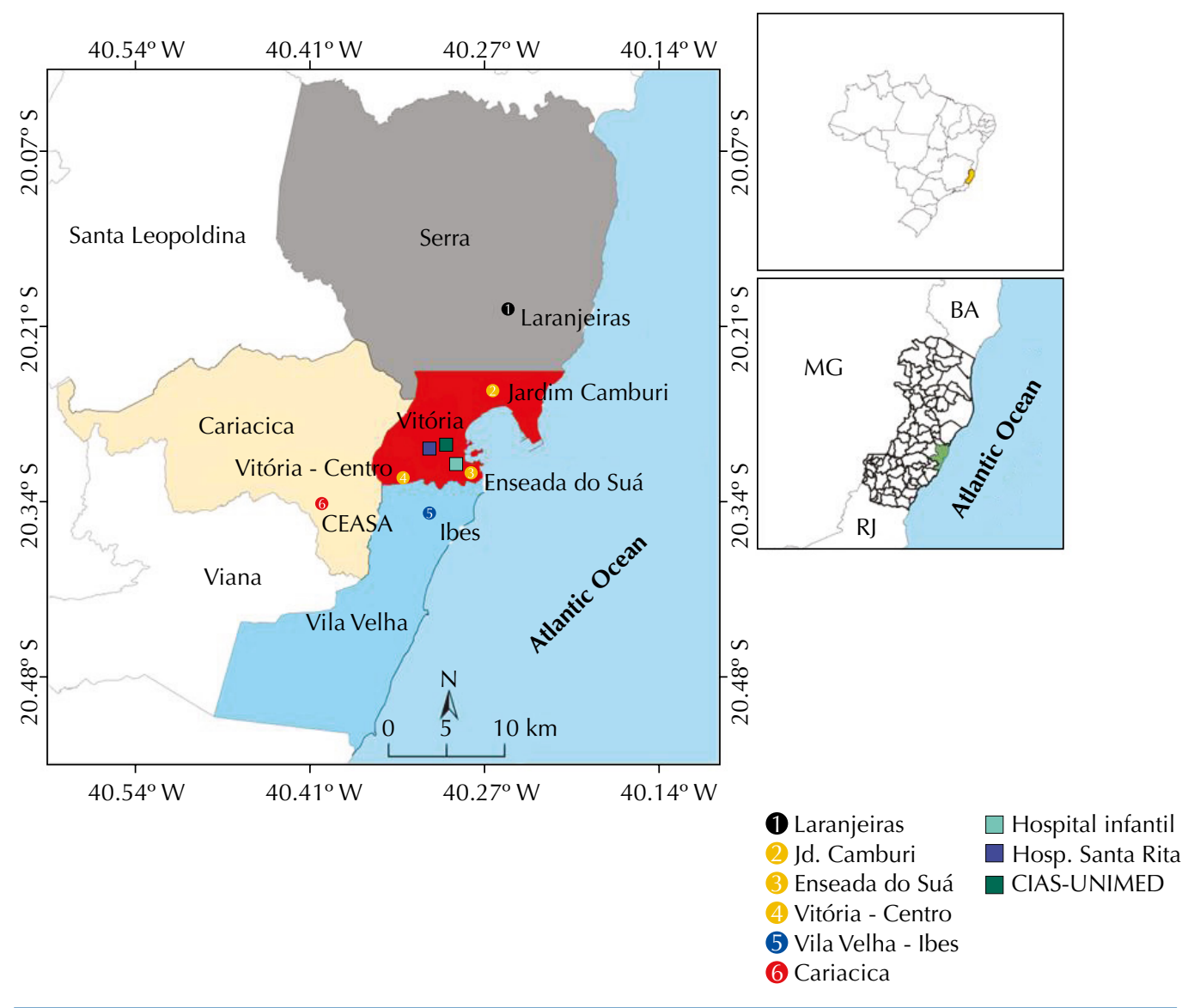

Figure 1. Location of sampling stations of fine particulate matter (1 to 6), and hospitals included in the study. Grande Vitória Region, ES, Southeastern Brazil, 2013-2014. 
Table 1. Descriptive statistics of acute respiratory events in children from zero to 12 years in three hospitals, concentration of fine particulate matter, and weather conditions in winter and summer. Grande Vitória Region, ES, Southeastern Brazil, 2013 to 2014.

\begin{tabular}{|c|c|c|}
\hline Parameters & Winter 2013 & Summer $2013 / 2014$ \\
\hline Total events & 5,786 & 3,201 \\
\hline Incidence (events/day) & 58 (SD 13) & 36 (SD 16) \\
\hline Nature of the event & $\mathrm{n}(\%)$ & n $(\%)$ \\
\hline Outpatient care & $5,446(94.0)$ & $3,053(95.0)$ \\
\hline Hospitalization & $340(6.0)$ & $148(5.0)$ \\
\hline \multicolumn{3}{|l|}{ Sex } \\
\hline Male & $3,083(53.0)$ & $1,707(53.0)$ \\
\hline Female & $2,703(47.0)$ & $1,494(47.0)$ \\
\hline \multicolumn{3}{|l|}{ Age group (years) } \\
\hline $0-2$ & $3,127(54.0)$ & $2,010(63.0)$ \\
\hline $3-6$ & $1,490(26.0)$ & $891(28.0)$ \\
\hline $7-12$ & $1,169(20.0)$ & $300(9.0)$ \\
\hline \multicolumn{3}{|l|}{$\mathrm{PM}_{2.5}\left(\mu \mathrm{g} / \mathrm{m}^{3}\right)$} \\
\hline Mean (SD) (median) & $11.4(3.1)(11.2)$ & $12.2(3.8)(10.5)$ \\
\hline $1^{\text {st }}$ quartile & 8.9 & 9.6 \\
\hline $3^{\text {rd }}$ quartile & 13.5 & 13.8 \\
\hline Minimum-Maximum & $5.9-19.7$ & $6.7-23.2$ \\
\hline \multicolumn{3}{|l|}{ Temperature $\left({ }^{\circ} \mathrm{C}\right)$} \\
\hline Mean (SD) (median) & $23.1(1.7)(22.9)$ & $28.2(1.1)(28.0)$ \\
\hline $1^{\text {st }}$ quartile & 21.7 & 28.0 \\
\hline $3^{\text {rd }}$ quartile & 24.5 & 29.0 \\
\hline Minimum-Maximum & $20.0-26.1$ & $23.0-30.0$ \\
\hline \multicolumn{3}{|l|}{ Relative humidity (\%) } \\
\hline Mean (SD) (median) & $77.0(6.4)(77.6)$ & $71.3(7.2)(69.0)$ \\
\hline $1^{\text {st }}$ quartile & 73.5 & 66.0 \\
\hline $3^{\text {rd }}$ quartile & 81.4 & 74.0 \\
\hline Minimum-Maximum & $61.0-92.3$ & $62.0-93.0$ \\
\hline Minimum-Maximum & $1.0-358.0$ & $2.0-360.0$ \\
\hline
\end{tabular}

Incidence given as mean; standard deviation (SD).

\section{RESULTS}

8,987 events were recorded by acute respiratory disease in children from zero to 12 years in both periods of collection; $64.0 \%$ of them occurred in the winter, with a daily mean of 58 (SD = 13). The mean of events was $36(\mathrm{SD}=6)$ events/day in summer. The number of patient care was slightly higher in male children in both seasons. There was a predominance of care to children from zero to two years old, and approximately $95.0 \%$ of cases did not require hospitalization (Table 1).

The mean concentration of $\mathrm{PM}_{2.5}$ for the whole period was $11.8 \mu \mathrm{g} / \mathrm{m}^{3}(\mathrm{SD}=3.5)$, with interquartile interval of $4.2 \mu \mathrm{g} / \mathrm{m}^{3}$ (Table 2).

The temperature and humidity values were within normal climatic means foreseen for winter and summer in RGV, with mean values of $22.3^{\circ} \mathrm{C}$ for temperature and $78.0 \%$ for relative humidity.

The events had higher and more uniform fluctuation in winter (Figure 2, A). In summer (Figure 2, B), we observed an increasing trend in the number of events and low daily fluctuation in the beginning of the period. The events showed a behavior similar to winter in the last month of summer. The mean concentration had high fluctuation, but was relatively uniform throughout the winter (Figure 2, C), while in summer (Figure 2, D) 
we observed a decreasing trend in the concentration of $\mathrm{PM}_{2.5}$ and low fluctuation in almost the entire period. In none of the days, the mean concentration exceeded the threshold of $25 \mu \mathrm{g} / \mathrm{m}^{3}$, maximum safety limit recommended by the WHO. There was agreement in the fluctuations of the original time series and of that modeled in winter, while the agreement was less evident in summer (Figure 3, A). Considering that some events included in this study, such as those of infectious and allergic nature, usually occur with a lag in time between the increased concentration of the pollutant and the observation of outcomes, the modeling was repeated with a lag of up to six days between the measure of $\mathrm{PM}_{2.5}$ and the occurrence of events. In this case, the agreement for the winter period was not as good as that considering the exposure to $\mathrm{PM}_{2.5}$ in the current day. However, the agreement has improved substantially for the summer (Figure 3, B). The best fit occurred when the tested temporal lag was of six days.

The results fitted in GAM for the six-day lag resulted in an estimate of the parameter $(\hat{\beta})$ of $0.0129(\mathrm{SD}=0.006)($ Table 2$)$.

Table 2. Estimated coefficients of the Generalized Additive Model, considering six-day lag between exposure to fine particulate matter and the hospital event. Grande Vitória Region, ES, Southeastern Brazil, 2013 to 2014.

\begin{tabular}{|c|c|c|c|c|c|}
\hline & & Estimated co & e GAM & & \\
\hline & Estimate & Standard error & $\mathrm{z}$ value & $\mathbf{p}$ & \\
\hline Intercept & 2.149 & 0.557 & 3.857 & 0.000 & $* * *$ \\
\hline Tuesday & -0.173 & 0.049 & -3.500 & 0.000 & $* * *$ \\
\hline Thursday & -0.197 & 0.049 & -4.029 & 0.000 & $* * *$ \\
\hline Saturday & -0.1227 & 0.048 & -2.513 & 0.012 & $*$ \\
\hline Holiday1 & 0.586 & 0.095 & 6.176 & 0.000 & $* * *$ \\
\hline Winter & 0.801 & 0.102 & 7.874 & 0.000 & $* * *$ \\
\hline Temperature & 0.049 & 0.013 & 3.645 & 0.000 & $* * *$ \\
\hline $\mathrm{PM}_{2.5}$ lag3 & 0.013 & 0.006 & 2.106 & 0.035 & $*$ \\
\hline
\end{tabular}

Holiday1: Independence and foundation day of Vitória

Significance $0{ }^{* * * \prime} 0.001^{1 * * \prime} 0.01^{\prime * \prime} 0.05^{\prime \prime} 0.1^{\prime \prime} 1$

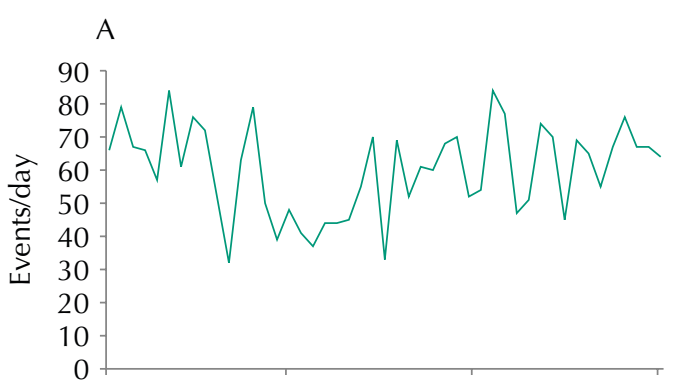

C

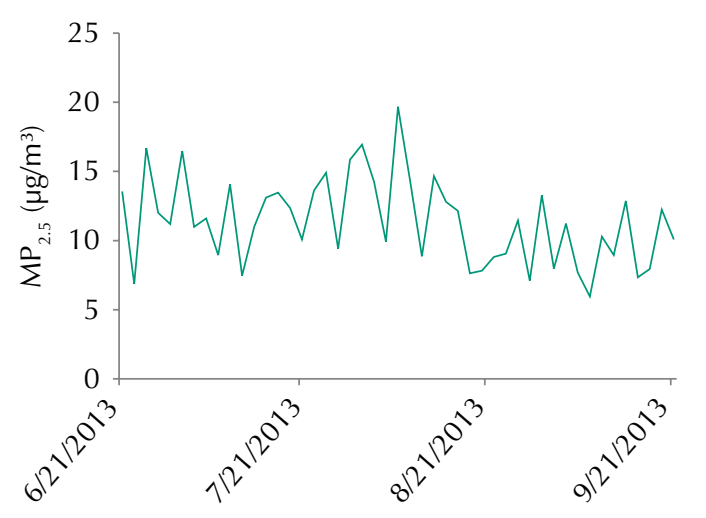

Elapsed days

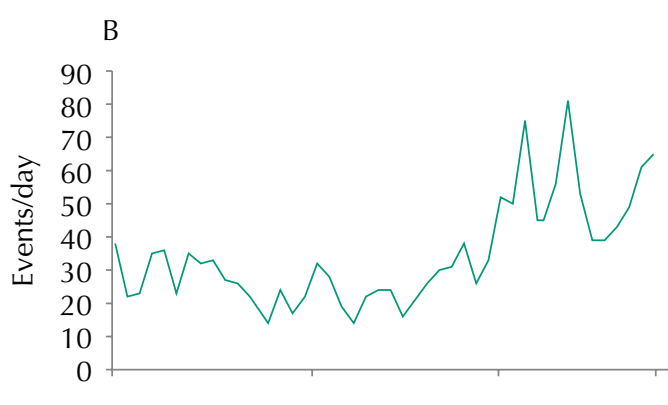

D

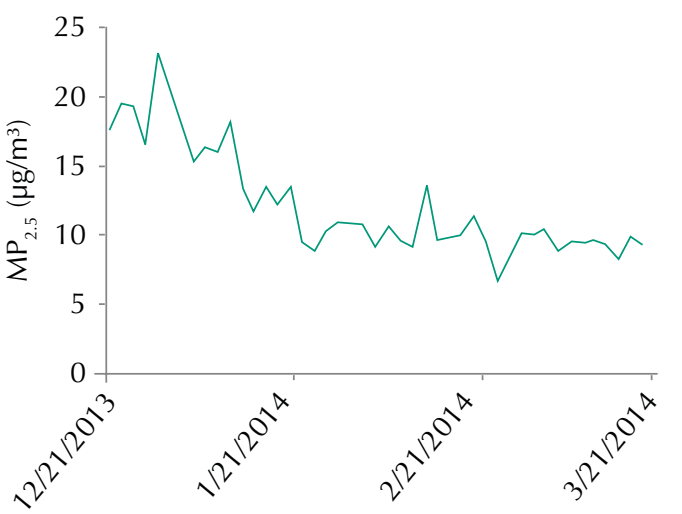

Figure 2. Time series of the number of acute respiratory events during (a) winter and (b) summer. Time series of concentration of fine particulate matter during (c) winter and (d) summer. Region of Grande Vitória, ES, Southeastern Brazil, 2013-2014. 


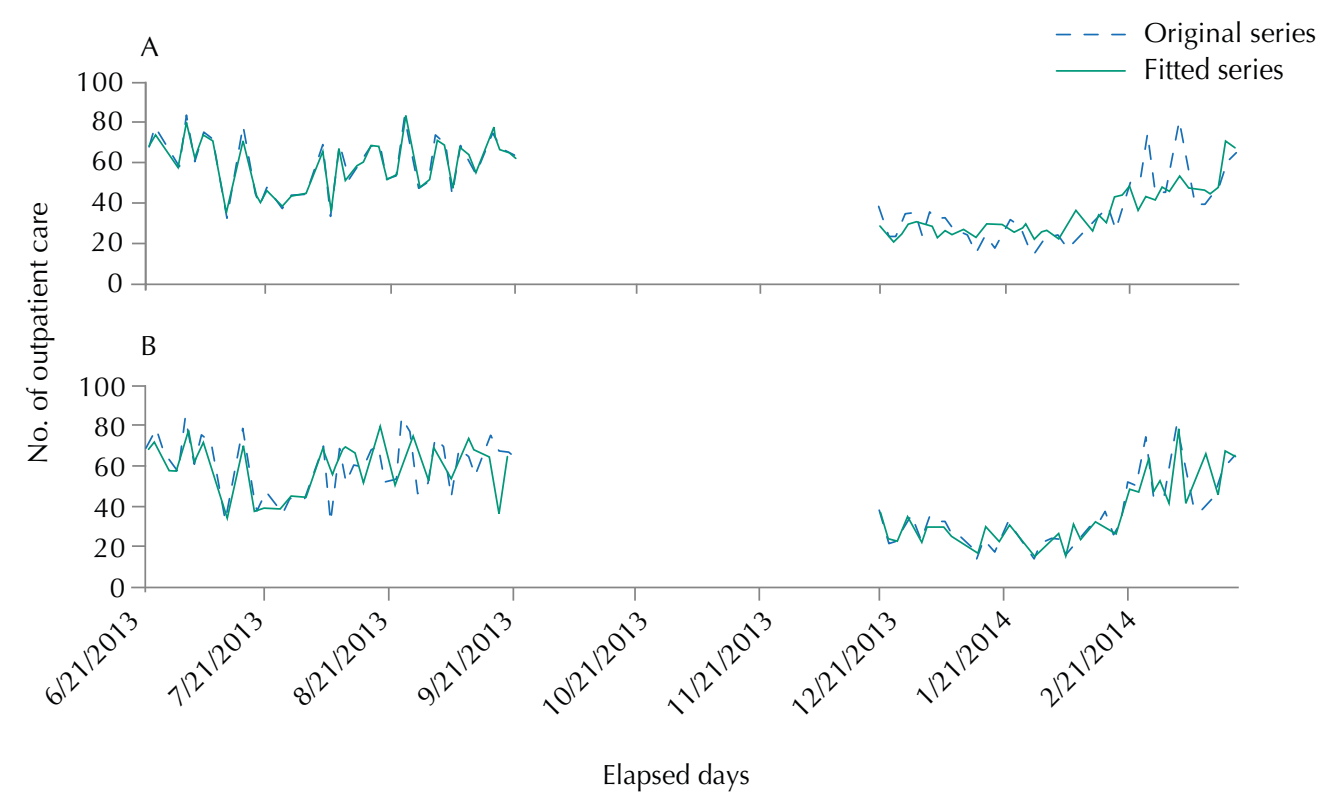

Figure 3. Fitting of the Generalized Additive Model considering exposure to pollutant (a) in the current day and (b) with six-day lag. The full line represents the original series and the dashed line represents the series fitted to lag 3. Region of Grande Vitória, ES, Southeastern Brazil, 2013 to 2014.

We estimated the RR of 1.0382 (95\%CI 0.990-1.089) and of 1.056 (95\%CI 1.003-1.111) for each increment of $4.2 \mu \mathrm{g} / \mathrm{m}^{3}$ in the concentration of $\mathrm{PM}_{2.5}$ in the RGV, respectively, for exposure at the current day and six-day lag between exposure and outcome. Therefore, children from zero to 12 years living in RGV suffered increase of almost $6.0 \%$ of probability to be suffering from acute episode of respiratory disease requiring hospital care at every increment of $4.25 \mu \mathrm{g} / \mathrm{m}^{3}$ of $\mathrm{PM}_{2.5}$ in the inhaled air.

\section{DISCUSSION}

The results of this study showed RR of $1.02(95 \% \mathrm{CI} 0.99-1.09)$ to the increase of $4.25 \mu \mathrm{g} / \mathrm{m}^{3}$ in the concentration of $\mathrm{PM}_{2.5}$ for exposure at the current day, and RR of 1.06 (95\%CI 1.00-1.11) to six-day lag from the exposure to $\mathrm{PM}_{25}$ of children under 12 years being affected by acute respiratory diseases, without significant differences between sexes. Previous studies investigated the effect of the lag between exposure to the pollutant and hospital event and indicated that, for larger lags, there is increased risk of association with short-term adverse effects of acute diseases ${ }^{8,11,13}$. Similar to other studies, the risk of disease in vulnerable groups was most evident with time lag between exposure and outcome ${ }^{11,22}$. Studies show that the PM in the atmosphere causes more significant effects on more vulnerable population subgroups, including children, especially in the early years of life, older adults, and those with preexisting diseases ${ }^{3,10,19}$.

The direct contact between particulate matter and respiratory system predisposes the occurrence of symptoms in short period of time. Children exhibit the body respiratory volume minute/weight greater than adults, which contributes to higher exposure to atmospheric pollutants ${ }^{3,12}$. Other factors, such as increased responsiveness of the epithelium and smooth muscle to $\mathrm{PM}_{2.5}$, can contribute to make this age group more susceptible to the effects of pollution, mainly children of up to two years, as observed in this study. However, the data collected is insufficient to detect different vulnerabilities between the age groups. Additional studies with longer series or data collection on a larger contingent of exposed people may explain this finding. For both modelings, in the current day or over six days of exposure, the children exposed presented RR of about $4.0 \%$ and $6.0 \%$, respectively. There was an increase of at least $2.0 \%$ in the value of RR estimated by the lagged GAM, when compared to the GAM 
in the current day. Other authors ${ }^{8,11,17}$ observed increase in the number of hospitalizations by respiratory diseases related to the growth of particles smaller than $10 \mu \mathrm{g} / \mathrm{m}^{3}$.

Stafoggia et al. ${ }^{22}$ (2013) found a strong association in the short-term between the increase of $10 \mu \mathrm{g} / \mathrm{m}^{3}$ of $\mathrm{PM}_{10}$ and $\mathrm{PM}_{2.5}$ with hospitalizations by respiratory diseases in eight Mediterranean cities in Europe. They estimated variation in the risk of 1.15\% (95\%CI0.21-2.11) for PM10 and of 1.36\% (95\%CI 0.23-2.49) for PM2.5 to exposure at the same day and five-day lag, respectively. Another study conducted in Copenhagen observed that, to an increase of $10 \mu \mathrm{g} / \mathrm{m}^{3}$ of PM2.5, the RR was 1.09 (95\%CI 1.04-1.13) for outcomes by asthma in children and adolescents up to 18 years $^{13}$. In Cordoba, Argentina, an increase of $10 \mu \mathrm{g} / \mathrm{m}^{3}$ of PM10 resulted in RR of 3.44\% (95\% CI 2.93-3.95) in male children younger than six years old and RR of 3.46\% (95\%CI 2.93-3.95) for female children in winter, spring, and autumn; while the RR was $3.21 \%$ (95\% CI 2.85-3.88) for males and 3.46\% (95\%CI 2.87-3.90) for females in summer².

In Piracicaba, SP, a research noted association between exposure to $\mathrm{PM}_{2.5}$ and hospitalization by respiratory diseases in children up to 10 years, with RR of 1.01 (95\%CI 1.00-1.02) on lag 1 and of 1.01 (95\%CI 1.00-1.02) on lag 37. A larger emission of $\mathrm{PM}_{2.5}$ due to biomass burning was associated with higher prevalence of hospitalizations by respiratory diseases in children up to four years and older adults over 65 years in 186 cities of Mato Grosso during 2004²0.

Previous studies in RGV showed association of hospital care by asthma in children up to six years and concentration of $\mathrm{PM}_{10}$ in the atmosphere ${ }^{6}$. Another study, also in RGV, presented an increase of $3.0 \%$ in the RR of hospital care by respiratory diseases in children younger than six years for the increase of $10.49 \mu \mathrm{g} / \mathrm{m}^{3}$ in the concentration of $\mathrm{PM}_{10}{ }^{21}$. These results together suggest that the finest PM seems to be more aggressive for the respiratory system of children, mainly for the younger ones.

We chose to consider children morbidity data from both public hospitals belonging to the Brazilian Unified Health System and private hospitals attended by the lower economic strata of the population. This aimed to exclude the economic strata as a variable in our analysis and their influence on exposure to risks of respiratory outcomes due to air pollution. However, we consider that the care carried out in these hospitals reflect the circadian fluctuations in all the population exposed to air pollution in RGV due to the PM2.5 emissions in the region.

The mean concentration of 24 hours of PM2.5 during the investigated period was $11.80 \mu \mathrm{g} / \mathrm{m}^{3}$. The mean concentration of PM2.5 was slightly higher in the summer, probably due to the rainfall that was below the expected mean for the period. In some periods RGV was under the influence of the South Atlantic Subtropical Ridge (SASR) in the summer. The winter of 2013 was rainier than usual, which may have contributed to the PM reduction in the atmosphere. In summer, precipitation was below the climatological normal value for the period. Moreover, in summer, RGV was under the influence of ASAS, with lower rainfall index, which may have affected the dispersal of concentrations of pollutants emitted, which might have contributed to increase PM2.5 concentration. On other days, RGV was under the influence of the South Atlantic Convergence Zone (SACZ). In the winter, on the other hand, August, usually quite dry, was anomalously rainier in 2013. This may explain the higher concentration levels found in summer if we consider that emissions remained constant.

Although the WHO presents guidelines for air quality associated with $\mathrm{PM}_{2.5}\left(25 \mu \mathrm{g} / \mathrm{m}^{3}\right.$ for short-term exposure, that is, average concentration of 24 hours), this same entity indicates that it is not possible to establish a minimum concentration of PM, below which no adverse health effects would occur. This study indicates that, even if the mean concentration of 24 hours of $\mathrm{PM}_{2.5}$ do not exceeded the upper limit of safety established by the WHO, even so one can identify the association between concentration of $\mathrm{PM}_{2.5}$ and incidence of acute respiratory events in children needing hospital care for a robust statistical model.

The study presents limitations because it was carried out in the short term, for only a period of winter and summer and with measurement of the pollutant on alternate days, given the unavailability of apparatus for continuous direct sampling of $\mathrm{PM}_{2.5}$. 
However, the use of portable devices enabled: sampling in places without automatic monitoring network of air quality, without electric power network and the conservation of samples for future analysis.

The results point to a significant relationship between concentration of $\mathrm{PM}_{2.5}$ and number of hospital care in children below 12 years, even with levels below the standards recommended by the WHO.

The complexity and variety of the sources of PM in RGV, besides increasing vehicular fleet, makes necessary to evaluate the concentration of $\mathrm{PM}_{2.5}$, its chemical composition, and the relationship of these variables with respiratory diseases. Further studies are needed to evaluate this relationship, especially in children, because they have more limited metabolic rates regarding exposure to chemicals.

\section{REFERENCES}

1. Albuquerque TTA, Andrade MF, Ynoue RY. Characterization of atmospheric aerosols in the city of São Paulo, Brazil: comparisons between polluted and unpolluted periods. Environ Monit Assess. 2012;184(2):968-84. DOI:10.1007/s10661-011-2013-y

2. Amarillo AC, Carreras HA. The effect of airborne particles and weather conditions on pediatric respiratory infections in Cordoba, Argentine. Environ Pollut. 2012;170:217-21. DOI:10.1016/j.envpol.2012.07.005

3. Arbex MA, Paula Santos U, Martins LC, Saldiva PHN, Pereira LAA, Braga ALF. A poluição do ar e o sistema respiratório. J Bras Pneumol. 2012;38(5):643-55. DOI:10.1590/S1806-37132012000500015

4. Bakonyi SMC, Oliveira IMD, Martins LC, Braga ALF.Poluição atmosférica e doenças respiratórias em crianças na cidade de Curitiba, PR. Rev Saude Publica. 2004;38(5):695-700. DOI:10.1590/S0034-89102004000500012

5. Braga ALF, Pereira LAA, Procópio M, André PA, Saldiva PHN. Associação entre poluição atmosférica e doenças respiratórias e cardiovasculares na cidade de Itabira, Minas Gerais, Brasil. Cad Saude Publica. 2007;23 Suppl 4:S570-8. DOI:10.1590/S0102-311X2007001600017

6. Castro HA, Hacon S, Argento R, Junger WL, Mello CF, Castiglioni Jr N et al. Air pollution and respiratory disease in the municipality of Vitória, Espírito Santo State, Brazil. Cad Saude Publica. 2007;23 Supp 4:S630-42. DOI:10.1590/S0102-311X2007001600023

7. Cesar ACG, Nascimento LFC, Carvalho Junior JA. Associação entre exposição ao material particulado e internações por doenças respiratórias em crianças. Rev Saude Publica. 2013;47(6):1209-12. DOI:10.1590/S0034-89102013000901209

8. Conceição GMS, Saldiva PHN, Singer JM. Modelos MLG e MAG para análise da associação entre poluição atmosférica e marcadores de morbi-mortalidade: uma introdução baseada em dados da cidade de São Paulo. Rev Bras Epidemiol. 2001;4(3):206-19. DOI:10.1590/S1415-790X2001000300007

9. Curtis L, Rea W, Smith-Willis P, Fenyves E, Pan Y. Adverse health effects of outdoor air pollutants. Env International. 2006;32(6):815-30. DOI:10.1016/j.envint.2006.03.012

10. Dockery DW, Pope CA 3rd, Xu X, Spengler JD, Ware JH, FAY ME et al. An association between air pollution and mortality in six U.S. cities. N Eng/ J Med. 1993;329(24):1753-9. DOI:10.1056/NEJM199312093292401

11. Gouveia N, Mendonça GAS, Leon AP, Correia JEM, Junger WL, Freitas CU et al. Poluição do ar e efeitos na saúde nas populações de duas grandes metrópoles brasileiras. Epidemiol Serv Saude. $2003 ; 12(1): 29-40$.

12. Heinrich J, Slama R. Fine particles, a major threat to children. Int / Hyg Environ Health. 2007;10(5):617-22. DOI:10.1016/j.ijheh.2007.07.012

13. Iskandar A, Andersen ZJ, Bønnelykke K, Ellermann T, Andersen KK, Bisgaard H. Coarse and fine particles but not ultrafine particles in urban air trigger hospital admission for asthma in children. Thorax. 2012;67(3):252-7. DOI:10.1136/thoraxjnl-2011-200324

14. Kampa M, Castanas E. Human health effects of air pollution. Environ Pollut. 2008;151(2):362-7. DOI:10.1016/j.envpol.2007.06.012 
15. Kappos AD, Bruckmann P, Eikmann T, Englert N, Heinrich $U$, Höppe $P$ et al. Health effects of particles in ambient air. Int J Hyg Environ Health. 2004;207(4):399-407. DOI:10.1078/1438-4639-00306

16. Kelly FJ, Fussell JC. Size, source and chemical composition as determinants of toxicity attributable to ambient particulate matter. Atmos Environ. 2012;60:504-26. DOI:10.1016/j.atmosenv.2012.06.039

17. Martins LC, Latorre MRDO, Cardoso MRA, Gonçalves FLT, Saldiva PHN, Braga ALF. Poluição atmosférica e atendimentos por pneumonia e gripe em São Paulo, Brasil. Rev Saude Publica. 2002;36(1):88-94. DOI:10.1590/S0034-89102002000100014

18. Provost EB, Chaumont A, Kicinski M, Cox B, Fierens F, Bernard A et al. Serum levels of club Cell secretory protein (Clara) and short- and long-term exposure to particulate air pollution in adolescents. Environ Int. 2014;68:66-70. DOI:10.1016/j.envint.2014.03.011

19. Saldiva PH, Pope CA 3rd, Schwartz J, Dockery DW, Lichtenfels AJ, Salge JM et al. Air pollution and mortality in elderly people: a time-series study in São Paulo, Brazil. Arch Environ Health. 1995;50(2):159-63.

20. Silva AMC, Mattos JE, Freitas SR, Longo KM, Hacon SS. Material particulado de queima de biomassa e doenças respiratórias no sul da Amazônia brasileira. Rev Bras Epidemiol. 2010;13(2):337-51. DOI:10.1590/S1415-790X2010000200015

21. Souza JB, Reisen VA, Santos JM, Franco GC. Componentes principais e modelagem linear generalizada na associação entre atendimento hospitalar e poluição do ar. Rev Saude Publica. 2014;48(3):451-8. DOI:10.1590/S0034-8910.2014048005078

22. Stafoggia M, Samoli E, Alessandrini E, Cadum E, Ostro B, Berti G et al. Short-term associations between fine and coarse particulate matter and hospitalization in Southern Europe: results from MED-PARTICLES project. Environ Health Perspectives. 2013;121(9):1026-33. DOI:10.1289/ehp.1206151

23. Wang X, Bi X, Sheng G, Fu J. Hospital indoor PM10/PM2.5 and associated trace elements in Guangzhou, China. Sci Total Environ. 2006;366(1):124-35. DOI:10.1016/j.scitotenv.2005.09.004

24. World Health Organization. WHO air quality guidelines: global update 2005: particulate matter, ozone, nitrogen dioxide and sulphur dioxide. Geneva: World Health Organization; 2006.

Authors' Contribution: Conception and planning of the study; data collection, analysis, and interpretation; writing and review of the manuscript: APN. Conception and planning of the study; writing and review of the manuscript:JMS. Conception and planning of the study; data analysis and interpretation; writing and review of the manuscript: JGM. Data collection, analysis, and interpretation; writing and review of the manuscript: JBS. Conception and planning of the study; review of the manuscript: NCRJ. Data analysis and interpretation; writing and review of the manuscript: VAR.

Acknowledgments: This research was possible by the collaboration of the Instituto Estadual de Meio Ambiente, Hospital Infantil Nossa Senhora da Glória, Hospital UNIMED Vitória and Hospital Santa Rita de Cássia.

Conflict of Interest: The authors declare no conflict of interest. 